\title{
Aplikasi Model Rantai Markov Dalam Pengelolaan Jalan di Kabupaten Bangkan Barat
}

\author{
Ahmad Sazali ${ }^{1}$, Bagus Hario Setiadji ${ }^{2}$, Bambang Haryadi ${ }^{3}$ \\ ${ }^{1}$ Dinas PUPR Kabupaten Bangka Barat \\ ${ }^{2}$ Departemen Teknik Sipil, Universitas Diponegoro, Semarang \\ ${ }^{3}$ Departemen Teknik Sipil, Universitas Negeri Semarang, Semarang \\ sazali.dpu@gmail.com bhsetiadji@yahoo.com haryaba@gmail.com
}

DOI: https://doi.org/10.21107/rekayasa.v12i2.5907

\begin{abstract}
ABSTRAK
Pemodelan kinerja perkerasan jalan sangat dibutuhkan dalam upaya mendapatkan gambaran informasi perubahan kondisi perkerasan jalan di masa mendatang. Penelitian ini fokus pada prediksi kondisi perkerasan jalan menggunakan metode rantai Markov dengan cara melakukan perkalian antara Matriks Probabilitas Transisi (MPT) dengan vektor kondisi awal. Data utama yang digunakan dalam pengembangan model ini adalah data kondisi perkerasan dan data histori penanganan jalan tahun 2016 - 2017. Aplikasi model rantai Markov pada jaringan jalan di Kabupaten Bangka Barat untuk periode lima tahun (2018 - 2022) dengan asumsi dilakukan penanganan untuk seluruh ruas jalan setiap tahun sesuai dengan jenis program penanganan (pemeliharaan rutin, pemeliharaan berkala, rehabilitasi dan rekonstruksi) berdasarkan batasan persentase kondisi kerusakan jalan. Gambaran perubahan kondisi jaringan jalan kabupaten yang dihasilkan dari penerapan model tersebut cukup optimal, dimana pada tingkat kondisi Baik (B) terus mengalami peningkatan. Sebaliknya, pada tingkat kondisi Rusak Berat (RB) terus mengalami penurunan setiap tahunnya. Hasil penelitian ini diharapkan dapat menjadi acuan bagi pengelola jalan dalam rangka perencanaan pengelolaan jaringan jalan.
\end{abstract}

Kata kunci : Kinerja perkerasan jalan; Rantai Markov; Pengelolaan jaringan jalan

\section{Application of Markov Chain Model In Road Management in Bangka Barat Regency}

\section{ABSTRACT}

Road pavement performance modeling is needed to get an overview of information about changes in road pavement conditions in the future. This research focuses on the prediction of road pavement conditions using the Markov chain method by multiplying the Transition Probability Matrix (TPM) with the initial condition vector. The main data used in the development of this model are pavement condition data and road handling history data for 2016-2017. Application of the Markov chain model in the road network in West Bangka Regency for a period of five years (2018 2022) with the assumption that handling is done for all roads every year according to the type of treatment program (routine maintenance, periodic maintenance, rehabilitation, and reconstruction) based on the percentage limit of road damage conditions. The description of changes in district road network conditions resulting from the application of the model is quite optimal, were at the level of good condition (B) continues to increase. Conversely, the level of severely damaged (RB) condition continues to decline every year. The results of this study are expected to be a reference for road managers in the framework of road network management planning.

Keywords : Road pavement performance; Markov chain; Road network management

\section{PENDAHULUAN}

Jaringan jalan merupakan komponen infrastruktur yang memiliki peran penting dalam menunjang kegiatan ekonomi suatu daerah. Sebagaimana disebutkan oleh Prasetyo and Firdaus (2009), bahwa pertumbuhan ekonomi Indonesia dipe-

\section{Article History:}

Received: August, 30th 2019; Accepted: September, $29^{\text {th }} 2019$ ISSN: 2502-5325 (Online) Terakreditasi Peringkat 3 oleh Kementerian Riset, Teknologi dan Pendidikan Tinggi (ARJUNA), berdasarkan Keputusan Direktur Jenderal Penguatan Riset dan Pengembangan No: 23/E/KPT/2019 tanggal 8 Agustus 2019 ngaruhi oleh ketersediaan infrastruktur, salah satu diantaranya adalah infrastruktur jalan. Seiring dengan peningkatan volume kendaraan dan bertambahnya umur pelayanan, jaringan jalan cenderung mengalami penurunan kondisi setiap tahunnya.

\section{Cite this as:}

Ahmad Sazali, A. Setiadji, B.H. Haryadi, B. (2019). Aplikasi Model Rantai Markov Dalam Pengelolaan Jalan di Kabupaten Bangkan Barat. Rekayasa, 12(2), 141-150. doi: https://doi.org/10.21107/rekayasa.v12i2.5907

(c) 2019 Ahmad Sazali, Bagus Hario Setiadji, Bambang Haryadi 
Oleh karena itu, diperlukan pengelolaan jalan yang baik dengan mempertahankan dan meningkatkan kondisi jaringan jalan, sehingga dapat digunakan sepanjang tahun secara efisien, aman dan memperhatikan faktor lingkungan (Paterson, 1994).

Dalam hal pengelolaan jaringan jalan yang berfokus pada perkerasan jalan, penyelenggara jalan dapat menerapkan sistem manajemen perkerasan (SMP) yang dilakukan mulai dari tahap perencanaan, perancangan, konstruksi, evaluasi pelayanan, serta pemeliharaan dan rehabilitasi (Li, 2005). Dalam penerapannya, SMP membutuhkan dukungan pemodelan kinerja jalan yang baik, karena dengan pengamatan dan prediksi kinerja yang tepat maka perencanaan pemeliharaan dan rehabilitasi yang disusun dalam SMP menjadi efektif dan efisien dalam hal pemanfaatan anggaran daerah. Model kinerja jalan yang dapat diprediksi adalah tingkat kerusakan perkerasan jalan.

Terdapat dua metode yang dapat digunakan untuk memprediksi kerusakan perkerasan jalan, yaitu model deterministik dan probabilistik yang bergantung pada cara mensimulasi penuaan perkerasan (Ortiz-García, Costello, \& Snaith, 2006). Model deterministik memprediksi kondisi dalam suatu nilai yang eksak berdasarkan fungsi matematis dari hasil obeservasi atau pengukuran penurunan kondisi, sedangkan model probabilistik memprediksi kondisi sebagai nilai probabilitas terjadinya berbagai kemungkinan hasil.

Menurut Ortiz-Garcia et al. (2006), metode probabilistik pada tingkat jaringan jalan, digunakan untuk memprediksi suatu rentang nilai dari variabel terikat, dimana perkerasan jalan akan mengalami perubahan dari berbagai kondisi menjadi kondisi yang lain dalam satu siklus. Salah satu metode yang tersedia untuk tujuan ini adalah teknik Markovian, yang merupakan teknik probabilistik yang telah terbukti sebagai alat yang efektif dalam memprediksi kinerja perkerasan di masa depan (Abaza \& Ashur, 1999).

Proses Markov mengasumsikan perubahan kondisi perkerasan bergantung pada kondisi perkerasan saat ini, sebagai tambahan prediksi performa perkerasan dengan rantai Markov juga dapat mengintegrasikan tingkat penurunan kondisi perkerasan dan tingkat perbaikan kondisi perkerasan (Abaza et al. 2004). Pada proses penggunaannya, model Markov memerlukan matriks probabilitas transisi (MPT) untuk mendefinsikan perubahan kondisi perkerasan jalan dari satu kondisi ke kondisi lainnya.

Keuntungan penggunaan model rantai Markov dalam memprediksi kondisi adalah kemampuan mengatasi ketidakpastian dari konstruksi, lingkungan dan kualitas bahan (Austroads 2012 dalam Arimbi 2015). Selain itu, model Markov memiliki kelebihan dalam hal kemudahannya untuk digunakan pada penyusunan rencana anggaran pemeliharaan setiap tahun dengan memberikan hasil yang optimum ditinjau dari segi biaya untuk jenis pemeliharaan rutin (Cahyaningrum, 2014). Penggunaan Markovian probabiliy process dalam memprediksi kondisi perkerasan jalan dapat membantu dalam membandingkan kondisi keseluruhan setelah dilakukan tindakan pemeliharaan pada jaringan jalan, sehingga tindakan pemeliharaan dapat dilakukan dengan tepat dan optimal (Surendrakumar et al. 2013).

Dalam usaha memperoleh perencanaan program pemeliharaan yang optimal pada jaringan jalan kabupaten, maka pengelola jalan memerlukan informasi perkiraan dari perubahan kondisi perkerasan jalan di waktu mendatang, baik perubahan akibat dilakukan penanganan maupun tidak dilakukannya penanganan terhadap kerusakan perkerasan jalan. Oleh karena itu, dibutuhkan suatu metode yang efektif untuk mengetahui kinerja jalan di masa mendatang, dengan cara memprediksi perkembangan kondisi perkerasan jalan.

Maksud dari penelitian ini adalah untuk mengetahui perubahan kondisi perkerasan jalan kabupaten di masa mendatang periode lima tahun dengan menerapkan model rantai Markov, berdasarkan jenis usulan tindakan penanganan terhadap kerusakan perkerasan jalan setiap tahunnya. Adapun wilayah studi dari penelitian ini adalah pada jaringan jalan di Kabupaten Bangka Barat Provinsi Kepulauan Bangka Belitung.

\section{STUDI LITERATUR}

Dibutuhkan teori-teori yang relevan untuk mendukung analisis dalam penelitian ini. 
Landasan teori yang digunakan adalah teori pemrograman pemeliharaan jalan dan teori pemodelan rantai Markov dalam sistem manajemen perkerasan jalan.

\section{Pemrograman Pemeliharaan Jalan}

Menurut Kementerian Pekerjaan Umum (2011), pemrograman pemeliharaan jalan meliputi kegiatan menentukan ruas/ segmen ruas jalan yang masuk dalam penanganan pekerjaan pemeliharaan rutin, pemeliharaan berkala, rehabilitasi dan rekonstruksi. Pemilihan jenis pemeliharaan yang dilakukan pada ruas jalan umumnya menggunakan suatu parameter tertentu sebagai alat bantu bagi pengelola jalan dalam memilih jenis pemeliharaan sesuai dengan kondisi ruas jalan yang dikelola.

Penentuan jenis program penanganan jalan mengacu pada Peraturan Menteri Pekerjaan Umum Nomor: 13/PRT/M/2011, Tentang Tata Cara Pemeliharaan dan Penilikan Jalan, yang ditampilkan pada Tabel 1.

Pelaksanaan kegiatan pemeliharaan yang dilakukan dengan baik, akan menjaga dan mempertahankan umur rencana perkerasan jalan, karena dapat memperlambat tingkat kerusakan ja-

Tabel 1. Penentuan Jenis Penanganan Jalan (Kementerian Pekerjaan Umum, 2011)

\begin{tabular}{lcl}
\hline Kondisi Jalan & $\begin{array}{c}\text { Persentase } \\
\text { Batasan } \\
\text { Kerusakan*) }\end{array}$ & \multicolumn{1}{c}{$\begin{array}{c}\text { Program } \\
\text { Penanganan }\end{array}$} \\
\hline Baik (B) & $<6 \%$ & Pemeliharaan Rutin \\
Sedang (S) & $6-<11 \%$ & $\begin{array}{l}\text { Pemeliharaan Berkala } \\
\text { Rusak Ringan }\end{array}$ \\
$\begin{array}{l}\text { Rehabilitasi } \\
\text { (RR) }\end{array}$ & $11-<15 \%$ & \\
$\begin{array}{l}\text { Rusak Berat } \\
\text { (RB) }\end{array}$ & $15 \%$ & Rekonstruksi/ \\
\hline
\end{tabular}

*)Persentase terhadap Luas Lapis Perkerasan Permukaan

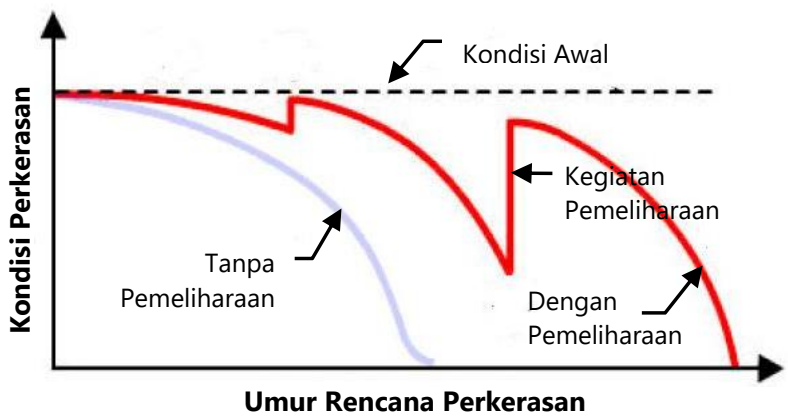

Gambar 1. Hubungan Kondisi dan Umur Rencana Perkerasan Jalan (Departemen Pekerjaan Umum, 2005) lan dan memperbaiki kondisi mendekati kondisi awal umur rencana. Sebaliknya bila tidak dilakukan pemeliharaan, maka jalan akan mengalami penurunan kondisi dan mengakibatkan umur rencana perkerasan jalan berkurang (Departemen Pekerjaan Umum, 2005). Hubungan antara kondisi dan umur rencana perkerasan jalan, ditampilkan pada Gambar 1.

\section{Sistem Manajemen Perkerasan}

Menurut Departemen Pekerjaan Umum (2005), Sistem Manajemen Perkerasan (SMP) adalah suatu sistem yang dibuat dalam rangka pengelolaan jalan yang digunakan untuk membantu dalam pengambilan keputusan para pembina jalan, sehingga pelaksanaan penyelenggaraan jalan dapat dilakukan dengan efektif dan efisien. SMP tersebut digunakan dalam mendukung kegiatan pemeliharaan asset jalan secara keseluruhan pada suatu pembinaan jaringan jalan yang dilaksanakan sesuai dengan tahapan kegiatan pemeliharaan jalan.

Efektifitas perencanaan penanganan pemeliharaan atau penentuan prioritas penanganan dalam SMP tergantung pada keakuratan prediksi kinerja perkerasan jalan dimasa depan dan pengamatan kondisi perkerasan saat ini (Li, 2005). Jika model penurunan kerusakan yang digunakan oleh pengelola jalan dalam menentukan kebijakan pemeliharaan tidak cukup merepresentasikan proses penurunan kerusakan yang sebenarnya, maka strategi pemeliharaan yang direncanakan akan jauh dari optimal (Durango \& Madanat, 2002). Oleh karena itu, pengukuran kinerja dan model prediksi kerusakan perkerasan jalan adalah komponen penting dari SMP.

Menurut Tjan and Pitaloka (2005), akurasi prediksi kondisi perkerasan masa depan adalah suatu keharusan, karena hal ini adalah bagian penting dari sistem. Salah satu metode yang tersedia untuk tujuan ini adalah teknik Markovian, yang merupakan teknik probabilistik yang lebih tepat untuk digunakan dalam memprediksi kondisi perkerasan di masa depan. Selain itu, Haas et al. (1994, dalam Arimbi 2015) menyatakan bahwa rantai Markov adalah cara terbaik untuk membuat model kinerja, karena keadaan masa depan dari elemen model diperkirakan hanya untuk keadaan elemen saat ini. 


\section{Model Rantai Markov}

Teori rantai Markov pertama kali dikemukakan oleh Prof. Andrei A. Markov pada tahun 1906, seorang matematikawan dari Rusia. Rantai Markov (Markov chain) adalah suatu teknik matematika yang bisa digunakan untuk pembuatan model bermacam-macam sistem dan proses bisnis. Teknik ini dapat digunakan untuk memperkirakan perubahan-perubahan di waktu yang akan datang dalam variabel-variabel dinamis atas dasar perubahan-perubahan dari variabel-variabel dinamis tersebut di waktu yang lalu. Teknik ini dapat juga digunakan untuk menganalisis kejadian - kejadian diwaktu mendatang secara matematis.

Prediksi kondisi masa depan dengan Markov Chain merupakan proses stokastik dan disusun berdasarkan 3 batasan (Ortiz-García et al., 2006), meliputi:

1. Batasan pertama adalah prosesnya diskrit terhadap waktu.

2. Proses harus memiliki state yang dapat dihitung atau terhingga.

3. Proses tersebut harus memenuhi properti Markov.

Dalam prediksi performa perkerasan jalan dengan model stokastik dapat dikatakan memenuhi properti Markov apabila kondisi perkerasan di masa mendatang bergantung pada kondisi perkerasan saat ini, bukan bergantung pada kondisi masa lampau. Kondisi perkerasan di masa mendatang dapat diprediksi menggunakan rumus (Ortiz-García et al. 2006; Panthi 2009), seperti ditampilkan pada Persamaan 1.

$a_{t}=a_{t-1} \times P=a_{0} \times P^{t}$

Keterangan :

$a_{t} \quad$ : distribusi kondisi pada waktu $t$

$a_{0} \quad$ : distribusi kondisi pada waktu ke-0, yang merupakan vektor awal $\left(a_{t-1}\right)$

$P^{t} \quad$ : MPT yang ditingkatkan dengan kontrol waktu $t$

$t \quad$ : waktu yang berlalu dalam satuan tahun

Dengan menggunakan vektor kondisi awal dan probabilitas transisi Markov, maka kondisi perkerasan di masa mendatang dapat diprediksi untuk waktu $(t)$ kapan pun (Panthi, 2009).

\section{Matrik Probabilitas Transisi (MPT)}

MPT pada model Markov mengekspresikan kemungkinan suatu kelompok perkerasan dengan kemiripan umur dan tingkat lalu lintas tertentu akan berpindah dari satu kondisi kerusakan ke kondisi kerusakan lain dan perioda waktu tertentu (Lytton, 1987). MPT adalah bagian dari Markov Process yang berperan mengubah kondisi awal dari perkerasan yang ditinjau. Selain itu, MPT berfungsi untuk menampilkan perubahan kondisi suatu keadaan ke keadaan lainnya pada waktu yang akan datang.

Pemodelan perubahan kondisi perkerasan terhadap waktu pada penyusunan MPT, dilambangkan dengan $\boldsymbol{P}$. Bentuk umum dari $\boldsymbol{P}$ ditampilkan pada Persamaan 2 (Ortiz-García et al. 2006; Pérez-Acebo et al. 2017).

$$
P=\left[\begin{array}{cccc}
p_{11} & p_{12} & \cdots & p_{1 n} \\
p_{21} & p_{22} & \cdots & p_{2 n} \\
: & & & : \\
p_{n 1} & p_{n 2} & \cdots & p_{n n}
\end{array}\right]
$$

MPT tersebut berisi segala informasi yang dibutuhkan untuk memodelkan pergerakan perubahan kondisi segmen. Perilaku proses Markovian dimodelkan dengan menggunakan probabilitas transisi $P_{i j}$, yang memberikan probabilitas dimana bagian dari segmen jalan yang ditinjau berpindah dari state $i$ ke state $j$ dalam satu siklus. Setiap MPT harus memenuhi kondisi sebagai berikut (Ortiz-García et al. 2006):

1. Jumlah masukan dari masing-masing baris sama dengan 1.

2. Semua nilai masukan tidak boleh negatif.

Sebuah model Markov dengan matriks transisi $5 \times 5$ menggunakan lima state kondisi yang berisi gabungan dari probabilitas kerusakan dan peningkatan, ditampilkan pada Persamaan 3 (Abaza et al. 2004).

$$
P=\left(\begin{array}{ccccc}
P_{11} & P_{12} & 0 & 0 & 0 \\
f_{21} & P_{22} & P_{23} & 0 & 0 \\
f_{31} & f_{32} & P_{33} & p_{34} & 0 \\
f_{41} & 0 & f_{43} & P_{44} & P_{45} \\
f_{51} & 0 & 0 & f_{54} & P_{55}
\end{array}\right)
$$

Keterangan :

$P_{i, i} \quad$ : probabilitas sisa dalam state kondisi yang 
sama setelah berlalu satu transisi

$P_{i, j} \quad$ : probabilitas penurunan kondisi dari $i$ ke $j$ setelah satu siklus transisi, $j=i+1$

$f_{i, j}:$ probabilitas akibat tindakan $\mathrm{M} \& \mathrm{R}, j<i$

Entri di atas diagonal utama $\left(P_{i, j} ; j>i\right)$ menunjukkan probabilitas transisi perkerasan ke kondisi yang lebih buruk setelah satu siklus transisi. Pada dasarnya, probabilitas tersebut mewakili tingkat kerusakan perkerasan, sehingga dapat disebut dengan probabilitas transisi kerusakan (Abaza, 2016). Kondisi jalan tidak akan bertambah buruk jika tindakan penanganan terhadap kerusakan perkerasan jalan terus dilaksanakan.

Entri di bawah diagonal utama $\left(f_{i, j} ; j<i\right)$ mewakili probabilitas transisi peningkatan kondisi akibat tindakan pemeliharaan dan rehabilitasi ( $M$ \& R). Probabilitas transisi perkerasan ke state kondisi yang lebih baik setelah satu transisi, disebut dengan probabilitas transisi peningkatan (Abaza, 2016). Variabel $f_{i j}$ adalah probabilitas yang menunjukkan bahwa bagian perkerasan akan meningkat dari state $i$ ke state $j$ dalam interval waktu tunggal sebagai hasil dari tindakan pemeliharaan dan rehabilitasi yang sedang aktif.

Abaza and Ashur (1999) menyebutkan bahwa tindakan pemeliharaan diterapkan pada state 2, 3, 4 dan 5 , yaitu variabel $f_{21}, f_{32}, f_{43}, f_{54}$ dan tidak ada pemeliharaan yang diterapkan untuk state 1 . Variabel ini menghasilkan satu langkah peningkatan dari state $i$ ke state $i-1$. Pekerjaan pemeliharaan (M) pada matriks didefinisikan sebagai pemeliharaan rutin yang terdiri dari pengisian retakan, penambalan lubang, dan teknik lain yang berlaku seperti chip seal dan slurry seal.

Sedangkan pekerjaan rehabilitasi $(\mathrm{R})$ pada matriks didefinisikan sebagai tindakan rehabilitasi utama yang mencakup pelapisan ulang (overlay), pelapisan ulang dengan rekonstruksi parsial (rekonstruksi terlokalisasi) dan rekonstruksi lengkap yang diterapkan untuk perkerasan di masing-masing state 3,4 dan 5 , yaitu $f_{31}, f_{41}, f_{51}$ dan dapat menghasilkan beberapa langkah peningkatan dari state $i$ ke state 1 . Nilai-nilai $f_{i j}$ akan lenyap tanpa adanya program pemeliharaan dan rehabilitasi (Abaza et al. 2004).

\section{Vektor Kondisi Awal}

Kondisi awal dari setiap proses dapat dideskripsikan oleh sebuah vektor awal yang menunjukkan probabilitas atau distribusi segmen perkerasan berada dalam kondisi atau keadaan tertentu. Kondisi awal digambarkan sebagai vektor awal, seperti ditampilkan pada Persamaan 4 (Ortiz-García et al. 2006).

$a_{0}=\left(\alpha_{1}, \alpha_{2}, \ldots, \alpha_{n}\right)$

Keterangan :

$\alpha_{i} \quad$ : nilai kondisi state $i$ pada tahun dasar $(t=0)$

Dengan menggunakan analogi perubahan kondisi perkerasan, vektor awal mengindikasikan kondisi awal segmen yang didefinisikan sebagai proporsi dari tiap rentang kondisi. Sama halnya dengan proporsi probabilitas transisi pada MPT, vektor awal juga harus memenuhi kondisi berikut (Ortiz-García et al. 2006):

1. Jumlah dari keseluruhuan $\alpha_{i}$ harus sama dengan 1.

2. Semua nilai masukan tidak boleh negatif.

\section{METODE PENELITIAN}

Secara keseluruhan, proses penelitian ini dilakukan dengan empat tahapan, dimana setiap tahapan memiliki hubungan sekuensial, yaitu keluaran tahap sebelumnya menjadi masukan ditahap berikutnya. Alur pikir dari penelitian ini, ditampilkan pada Gambar 2.

Tahap pertama, studi literatur dilakukan untuk mengetahui lebih dalam mengenai model rantai Markov sebagai metode probabilistik yang sering digunakan dalam memprediksi kejadian kejadian di masa mendatang secara matematis dan untuk mencari referensi kegiatan sejenis yang pernah dilakukan sebelumnya. Selain itu, studi literatur dilakukan untuk mengumpulkan informasi mengenai pola pemeliharaan jalan yang telah dilakukan selama ini di wilayah Kabupaten Bangka Barat.

Tahap kedua adalah pengumpulan data, dimana ruas jalan yang ditinjau dalam penelitian ini adalah ruas jalan yang memiliki status jalan kabupaten yang berada dalam jaringan jalan di wilayah Kabupaten Bangka Barat. Keseluruhan data yang digunakan adalah periode tahun 2016- 


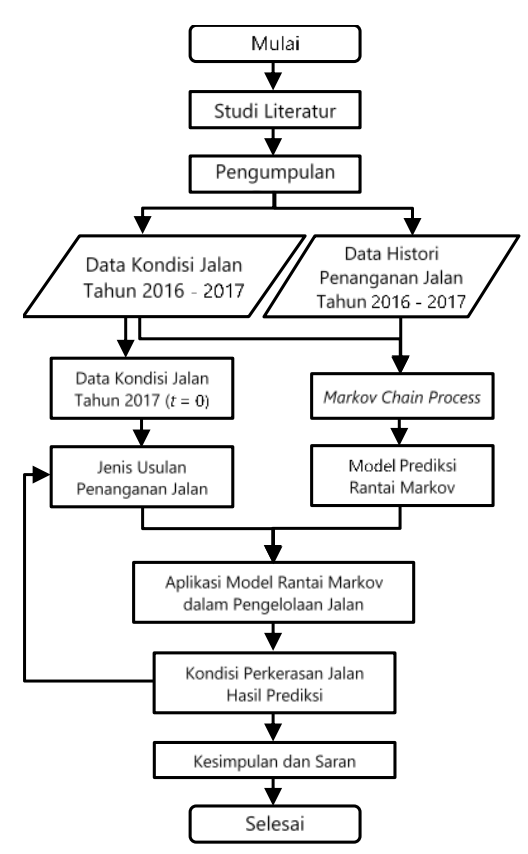

Gambar 2. Alur Pikir Penelitian

2017. Jumlah sampel ruas jalan yang digunakan pada penelitian ini berjumlah 105 ruas, dibagi menjadi dua kelompok data. Kelompok pertama adalah sejumlah 85 ruas jalan digunakan untuk pemodelan rantai Markov. Kelompok kedua, yaitu sisanya sejumlah 20 ruas jalan digunakan sebagai sampel untuk penerapan model prediksi kondisi perkerasan jalan dimasa mendatang periode $2018-2022$.

Data yang digunakan dalam penelitian ini merupakan data sekunder yang diperoleh dari instansi terkait, meliputi: (1) Data kondisi eksisting perkerasan jalan, merupakan variabel yang akan digunakan dalam pemodelan, dimana kondisi jalan terbagi menjadi empat tingkatan, yaitu: Baik, Sedang, Rusak Ringan dan Rusak Berat; (2) Data histori penanganan jalan, digunakan untuk mengetahui jenis penanganan dan besaran alokasi biaya yang telah dilaksanakan di tahun sebelumnya.

Tahap ketiga adalah analisis, yang diawali dengan Markov chain process. Secara garis besar, ada empat langkah yang dilakukan dalam proses pemodelan ini, yaitu: (1) Penentuan kriteria state kondisi; (2) Perhitungan distribusi kondisi awal; (3) Penyusunan matriks probabilitas transisi; (4) Model prediksi kondisi perkerasan.
Tabel 2. Kriteria State Kondisi

\begin{tabular}{crl}
\hline State Kondisi & Tingkat Kondisi Ruas Jalan \\
\hline 1 & Baik & (B) \\
2 & Sedang & (S) \\
3 & Rusak Ringan & (RR) \\
4 & Rusak Berat & (RB) \\
\hline
\end{tabular}

Kriteria state kondisi ditentukan menjadi empat state kondisi, sesuai dengan jumlah dari jenis tingkatan kondisi yang ada, yaitu kondisi Baik (B), Sedang (S), Rusak Ringan (RR) dan Rusak Berat (RB). State 1 mewakili kondisi terbaiknya, dimana perkerasan jalan berada pada tingkat kondisi Baik (B), sedangkan state 4 mewakili kondisi terburuknya, dimana perkerasan jalan berada pada tingkat kondisi Rusak Berat (RB). Kriteria state kondisi perkerasan jalan untuk empat jenis tingkatan kondisi yang ada, ditampilkan pada Tabel 2 .

Pada penelitian ini, akhir tahun 2017 dijadikan sebagai tahun dasar $(t=0)$. Dari data kondisi jalan tahun 2016 - 2017, distribusi kondisi perkerasan dapat dihitung berdasarkan klasifikasi nilai kondisi yang telah ditentukan. Proporsi distribusi diperoleh dengan cara membandingkan panjang segmen jalan yang berada pada kondisi tertentu dengan panjang total dari ruas jalan yang ditinjau. Setelah diperoleh nilai distribusi kondisi awal untuk seluruh state, selanjutnya vektor kondisi awal $\left(a_{0}\right)$ dapat disusun sesuai dengan Persamaan 4.

Selanjutnya disusun MPT berdasarkan data transisi kondisi jalan dalam satu tahun operasional perkerasan jalan (tahun 2016 - 2017). Kategori yang digunakan adalah dengan penanganan, artinya terdapat tindakan penanganan terhadap kerusakan jalan, sehingga nilai kondisi perkerasan dimungkinkan akan berpindah ke keadaan yang lebih baik setelah satu siklus. Jenis program penanganan jalan dapat berupa pemeliharaan rutin, pemeliharaan berkala, rehabilitasi dan rekonstruksi atau peningkatan. MPT yang disusun pada kategori ini berisikan nilai probabilitas transisi peningkatan.

Dengan diperolehnya vektor kondisi awal $\left(a_{0}\right)$ dan MPT dari hasil perhitungan, maka terbentuk model rantai Markov. Perhitungan estimasi kondisi perkerasan tahun ke $t$ menggunakan model prediksi ini dilakukan dengan cara 
mengalikan vektor kondisi awal dengan MPT, sesuai dengan Persamaan (1).

Setelah mendapatkan model prediksi rantai Markov, maka aplikasi model untuk memprediksi kondisi perkerasan jalan dimasa mendatang dapat dilakukan. Akan tetapi, sebelum masuk ke tahap aplikasi prediksi, terlebih dahulu ditentukan jenis usulan penanganan sesuai dengan kategori yang dibuat, berdasarkan data kondisi pada tahun dasar $(t=0)$. Penentuan jenis penanganan ini, akan berpengaruh pada MPT mana yang akan digunakan dalam perhitungan. Sebagai contoh, ruas jalan Petar - Ranggi memiliki nilai kondisi $R R+R B$ sejumlah 36,1\%, maka jenis usulan penanganan yang sesuai adalah rekonstruksi (>15\%). Dari kasus tersebut, maka aplikasi prediksi kondisi jalan untuk tahun pertama $(t=1)$ dilakukan dengan cara mengalikan vektor kondisi awal dengan MPT rekonstruksi, yang berisikan probabilitas transisi peningkatan akibat dari tindakan rekonstruksi.

Aplikasi prediksi dilakukan untuk periode lima tahun (2018 - 2022). Nilai kondisi hasil prediksi tahun pertama $(t=1)$ menjadi masukan dalam perhitungan prediksi untuk tahun kedua $(t=2)$. Prediksi kondisi untuk tahun berikutnya dilakukan dengan cara yang sama dan dilakukan sampai dengan akhir tahun kelima $(t=5)$.

Tahap keempat adalah kesimpulan dan saran, yaitu dari hasil analisis akan ditarik kesimpulan dan disampaikan saran bagi para peneliti selanjutnya yang akan mengkaji hal sejenis untuk mendapatkan hasil yang lebih baik.

\section{HASIL DAN PEMBAHASAN}

Penerapan model rantai Markov dalam pengelolaan jalan kabupaten dilakukan dengan simulasi berdasarkan rencana pelaksanaan dari program penanganan jalan yang dilakukan secara ideal, terdiri dari jenis penanganan pemeliharaan rutin, pemeliharaan berkala, rehabilitasi dan peningkatan, yang ditentukan sesuai dengan nilai kondisi kerusakan perkerasan jalan. Model prediksi rantai Markov yang digunakan untuk memprediksi peningkatan kondisi pada simulasi ini menggunakan nilai probabilitas transisi peningkatan. Prediksi kondisi perkerasan jalan untuk tindakan pemeliharaan dilakukan menggunakan MPT dengan nilai probabilitas transisi yang dipengaruhi oleh variabel pemeliharaan $(\mathrm{M})$, sedangkan prediksi kondisi untuk tindakan rehabilitasi dan peningkatan menggunakan MPT dengan nilai probabilitas transisi yang dipengaruhi oleh variabel rehabilitasi dan peningkatan $(R)$.

MPT yang digunakan dalam model ini merupakan probabilitas transisi kondisi perkerasan tahun 2016 - 2017, dengan vektor kondisi awal $\left(a_{0}\right)$ yang disusun berdasarkan distribusi kondisi awal tahun 2017, dimana tahun 2017 digunakan sebagai tahun dasar $(t=0)$. Sebagai contoh hasil penyusunan MPT dari pemodelan rantai Markov untuk penerapan model pada ruas jalan Petar Ranggi, disajikan pada Persamaan (5), (6) dan (7).

MPT Rekonstruksi dan Rehabilitasi (R):

$P=\left[\begin{array}{llll}1.00 & 0.00 & 0.00 & 0.00 \\ 0.00 & 1.00 & 0.00 & 0.00 \\ 0.62 & 0.00 & 0.38 & 0.00 \\ 0.62 & 0.00 & 0.00 & 0.38\end{array}\right]$

MPT Pemeliharaan (M):

$P=\left[\begin{array}{llll}1.00 & 0.00 & 0.00 & 0.00 \\ 0.90 & 0.10 & 0.00 & 0.00 \\ 0.00 & 0.30 & 0.70 & 0.00 \\ 0.00 & 0.00 & 0.38 & 0.62\end{array}\right]$

Vektor kondisi awal:

$a_{0}=\left(\begin{array}{llll}0.39 & 0.25 & 0.18 & 0.18\end{array}\right)$

Prediksi kondisi perkerasan dilakukan untuk 20 ruas jalan yang mewakili jaringan jalan kabupaten dengan panjang total $85.71 \mathrm{Km}$, dimana posisi kondisi eksisting (2017) untuk tingkat kondisi Baik $(B)=62.9 \%$, Sedang $(S)=20.4 \%$, Rusak Ringan $(R R)=11.0 \%$ dan Rusak Berat $(R B)=5.7 \%$. Sebagai contoh aplikasi model rantai Markov dalam prediksi kondisi perkerasan jalan tahun 2018 - 2022 untuk ruas jalan Petar - Ranggi, ditampilkan pada Tabel 3.

Tabel 3. Aplikasi Model Rantai Markov dalam Prediksi Kondisi Perkerasan Ruas Jalan Petar - Ranggi

\begin{tabular}{|c|c|c|c|c|c|c|c|c|}
\hline \multirow{2}{*}{ No. } & \multirow{2}{*}{ Ruas Jalan } & \multirow{2}{*}{ Keterangan } & \multicolumn{6}{|c|}{ Persentase Kondisi Kerusakan Perkerasan Jalan } \\
\hline & & & 2017 & 2018 & 2019 & 2020 & 2021 & 2022 \\
\hline \multirow{7}{*}{1} & \multirow{7}{*}{$\begin{array}{l}\text { Petar - } \\
\text { Ranggi }\end{array}$} & Baik & $38.8 \%$ & $61.1 \%$ & $69.7 \%$ & $92.1 \%$ & $95.1 \%$ & $96.2 \%$ \\
\hline & & Sedang & $25.0 \%$ & $25.0 \%$ & $25.0 \%$ & $3.4 \%$ & $1.2 \%$ & $0.9 \%$ \\
\hline & & Rusak Ringan & $17.8 \%$ & $6.8 \%$ & $2.6 \%$ & $2.8 \%$ & $2.6 \%$ & $2.2 \%$ \\
\hline & & Rusak Berat & $18.3 \%$ & $7.0 \%$ & $2.7 \%$ & $1.7 \%$ & $1.0 \%$ & $0.6 \%$ \\
\hline & & Kond. Mantap & $63.9 \%$ & $86.2 \%$ & $94.7 \%$ & $95.5 \%$ & $96.4 \%$ & $97.2 \%$ \\
\hline & & Kond. Tidak Mantap & $36.1 \%$ & $13.8 \%$ & $5.3 \%$ & $4.5 \%$ & $3.6 \%$ & $2.8 \%$ \\
\hline & & Jenis Penanganan & - & Peningkatan & Rehabilitasi & P. Rutin & P. Rutin & P. Rutin \\
\hline
\end{tabular}


Persentase kondisi ruas jalan Petar - Ranggi tahun 2017, merupakan kondisi eksisting yang digunakan sebagai tahun dasar $(t=0)$ dalam prediksi kondisi perkerasan jalan untuk tahun 2018 sampai dengan tahun 2019. Kondisi mantap adalah jumlah dari nilai kondisi Baik (B) dan Sedang (S), sedangkan kondisi tidak mantap adalah jumah dari nilai kondisi Rusak Ringan (RR) dan Rusak Berat (RB).

Tabel 3. menunjukkan kondisi tidak mantap $(R R+R B)$ di tahun 2017 sebesar $36.1 \%$ yang berada diatas $15 \%(R R+R B>15 \%)$, sehingga jenis usulan penanganan yang sesuai adalah rekonstruksi atau peningkatan jalan. Dengan menggunakan MPT peningkatan yang diperoleh dari nilai probabilitas transisi akibat pengaruh variabel peningkatan, maka prediksi kondisi perkerasan jalan untuk tahun pertama (2018) menghasikan nilai sebesar $13.8 \%$. Dari nilai kondisi ini, maka jenis usulan penanganan yang sesuai untuk tahun berikutnya adalah rehabilitasi, karena berada pada interval $11-15 \%$. Prediksi kondisi perkerasan jalan untuk tahun kedua (2019) menghasikan nilai sebesar 5.3\%. Prediksi kondisi untuk tahun berikutnya dilakukan dengan cara yang sama sampai dengan akhir tahun kelima (2022), yang menghasilkan nilai kondisi sebesar $2.8 \%$.

Hasil simulasi untuk ruas jalan Petar - Ranggi yang ditampilkan pada Tabel 3. menunjukkan kondisi mantap $(B+S)$ meningkat setiap tahunnya, akibat dari tindakan penanganan kerusakan jalan yang dilakukan setiap tahun atau tanpa adanya penundaan penanganan terhadap ruas jalan tersebut. Dapat dilihat pada Tabel 3. bahwa hasil prediksi menggunakan model rantai Markov untuk jenis program rekonstruksi/ peningkatan jalan mengalami kenaikan yang lebih besar pada nilai kondisi mantap jika dibandingkan dengan program pemeliharaan rutin. Oleh karena itu, untuk mempercepat perolehan nilai kondisi mantap yang ideal, maka penentuan jenis program penanganan jalan harus sesuai dengan kondisi kerusakan yang dialami dan tidak dilakukan penundaan tindakan penanganan kerusakan jalan.

Pola penanganan jalan dalam periode lima tahun (2018 - 2022) yang dihasilkan berdasarkan nilai kondisi jalan hasil prediksi menggunakan model rantai Markov menghasilkan pola yang cukup baik, dimana jenis program penanganan terus bergeser dari pekerjaan berat menuju pekerjaan ringan (rekonstruksi - rehabilitasi - pemeliharaan berkala - pemeliharaan rutin). Hal ini disebabkan oleh penurunan yang terus terjadi pada kondisi tidak mantap setiap tahunnya. Rekapitulasi hasil prediksi kondisi perkerasan untuk seluruh jaringan jalan sesuai dengan simulasi program penanganan jalan selama lima tahun (2018 2022), ditampilkan pada Tabel 4. dan hasil ploting ke dalam grafik disajikan pada Gambar 3.

Tabel 4. Rekapitulasi Hasil Prediksi Kondisi Perkerasan Jaringan Jalan Kabupaten

\begin{tabular}{|c|c|c|c|c|c|c|c|c|c|c|c|c|c|}
\hline \multirow{2}{*}{\multicolumn{2}{|c|}{ Tingkat Kondisi }} & \multicolumn{2}{|c|}{2017} & \multicolumn{2}{|c|}{2018} & \multicolumn{2}{|c|}{2019} & \multicolumn{2}{|c|}{2020} & \multicolumn{2}{|c|}{2021} & \multicolumn{2}{|c|}{2022} \\
\hline & & $\mathrm{Km}$ & $\%$ & Km & $\%$ & $\mathbf{K m}$ & $\%$ & Km & $\%$ & Km & $\%$ & Km & $\%$ \\
\hline Baik & (B) & 53.88 & $62.9 \%$ & 56.26 & $65.6 \%$ & 72.85 & $85.0 \%$ & 79.78 & $93.1 \%$ & 81.94 & $95.6 \%$ & 82.99 & $96.8 \%$ \\
\hline Sedang & (S) & 17.50 & $20.4 \%$ & 21.60 & $25.2 \%$ & 7.89 & $9.2 \%$ & 2.28 & $2.7 \%$ & 1.18 & $1.4 \%$ & 0.82 & $1.0 \%$ \\
\hline Rusak Ringan & (RR) & 9.46 & $11.0 \%$ & 5.99 & $7.0 \%$ & 4.07 & $4.7 \%$ & 3.09 & $3.6 \%$ & 2.28 & $2.7 \%$ & 1.71 & $2.0 \%$ \\
\hline Rusak Berat & (RB) & 4.87 & $5.7 \%$ & 1.87 & $2.2 \%$ & 0.91 & $1.1 \%$ & 0.56 & $0.7 \%$ & 0.31 & $0.4 \%$ & 0.19 & $0.2 \%$ \\
\hline
\end{tabular}

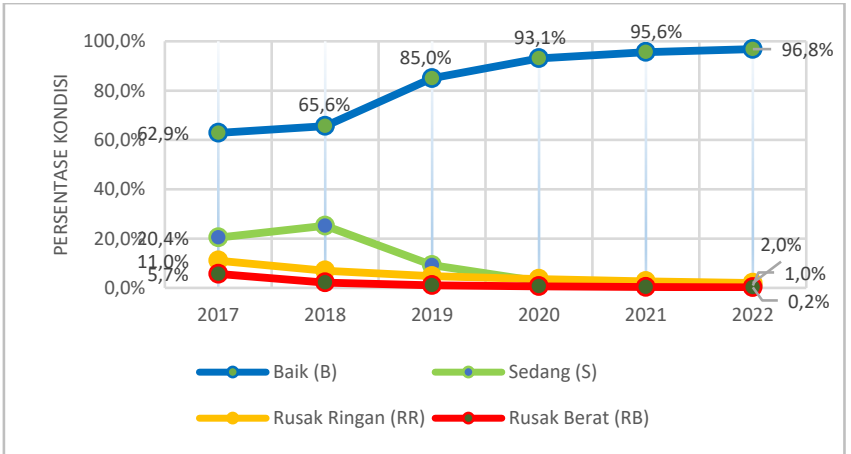

Gambar 1. Grafik Perubahan Kondisi Perkerasan Jaringan Jalan Kabupaten 
Tabel 4. menunjukkan bahwa simulasi dalam program penanganan jalan tingkat jaringan untuk jangka waktu 5 (lima) tahun menghasilkan nilai kondisi Baik (B) menjadi 96.8\% di akhir tahun 2022. Sebaliknya, nilai kondisi Rusak Berat (RB) terus mengalami penurunan sampai dengan $0.2 \%$. Hal ini menunjukkan bahwa rencana program pengelolaan jalan kabupaten pada simulasi ini cukup optimal, dimana simulasi dilakukan dengan asumsi bahwa tindakan penanganan untuk seluruh jaringan jalan dilakukan setiap tahun tanpa ada penundaan. Grafik pada Gambar 1. membuktikan bahwa tindakan penanganan terhadap kerusakan jalan yang dilakukan secara rutin dan konsisten akan memberikan hasil yang baik dari segi nilai kondisi perkerasan jalan.

\section{KESIMPULAN DAN SARAN}

Aplikasi model rantai Markov pada jaringan jalan kabupaten untuk periode lima tahun (2018 2022) menggunakan nilai MPT dari transisi kondisi jalan tahun 2016 - 2017, dengan asumsi penanganan kerusakan untuk seluruh jaringan jalan dilakukan setiap tahun tanpa ada penundaan, menghasilkan gambaran perubahan kondisi perkerasan jalan yang sangat baik, dimana kondisi Baik (B) mengalami peningkatan setiap tahun, dari 62.9\% di tahun 2017 menjadi 96.8\% di tahun 2022. Informasi dari hasil prediksi ini akan sangat membantu dalam pengelolaan jaringan jalan kabupaten dalam rangka menjaga dan mempertahankan kondisi jalan pada tingkat yang laik.

Model yang dihasilkan dari pengembangan pada penelitian ini bersifat lokal, dalam arti penerapannya dilakukan untuk wilayah studi, yaitu jaringan jalan di Kabupaten Bangka Barat. Penggunaan model untuk daerah lain di luar wilayah studi harus dengan pertimbangan tertentu atau dapat dilakukan dengan cara melakukan penyesuaian pada perhitungan vektor kondisi awal $\left(a_{0}\right)$ dan MPT sesuai dengan pola penanganan dan data kondisi jalan yang ada.

\section{PENGHARGAAN}

Terimakasih kepada BPSDM Kementerian PUPR, Dinas PUPR Kabupaten Bangka Barat dan Departemen Teknik Sipil Universitas Diponegoro atas semua support yang diberikan untuk penelitian ini.

\section{DAFTAR PUSTAKA}

Abaza, K. A. (2016). Simplified stagedhomogenous Markov model for flexible pavement performance prediction. Road Materials and Pavement Design, 17(2), 365381.

https://doi.org/10.1080/14680629.2015.108 3464

Abaza, K. A., \& Ashur, S. A. (1999). Optimum Decision Policy for Management of Pavement Maintenance and Rehabilitation Optimum Decision Policy for Management of Pavement, (February 2015). https://doi.org/10.3141/1655-02

Abaza, K. A., Ashur, S. A., \& Al-Khatib, I. A. (2004). Integrated Pavement Management System with a Markovian Prediction Model. Journal of Transportation Engineering, 130. https://doi.org/10.1061/(ASCE)0733947X(2004)130

Arimbi, G. (2015). Network-Level Pavement Performance Prediction Modelling with Markov Chains (Predicting the Condition of Road Network For Rijkswaterstaat). Delf University of Technology.

Cahyaningrum, E. K. (2014). Pemodelan Estimasi Kerusakan Perkerasan Jalan (Studi Kasus Ruas Jalan Nasional di Wilayah Kerja PPK 3, Satker PJN Wilayah Propinsi DIY). Universitas Gajah Mada.

Departemen Pekerjaan Umum. (2005). Teknik Pengelolaan Jalan: Seri Panduan Pemeliharaan Jalan Kabupaten. Bandung: Departemen Pekerjaan Umum.

Durango, P. L., \& Madanat, S. M. (2002). Optimal maintenance and repair policies in infrastructure management under uncertain facility deterioration rates: an adaptive control approach, 36, 763-778.

Kementerian Pekerjaan Umum. Peraturan Menteri Pekerjaan Umum Nomor: 13/PRT/M/2011 Tentang Tata Cara Pemeliharaan dan Penilikan Jalan (2011). Jakarta.

Li, Z. (2005). A Probabilistic and Adaptive Approach to Modeling Performance of Pavement Infrastructure. University of Texas.

Lytton, R. L. (1987). Concepts of Pavement Performance Prediction and Modeling. In Second North American Conference on Managing Pavements (pp. 2.3-2.19). Toronto. 
Ortiz-García, J. J., Costello, S. B., \& Snaith, M. S. (2006). Derivation of Transition Probability Matrices for Pavement Deterioration Modeling. Journal of Transportation Engineering, 132(2), 141-161. https://doi.org/10.1061/(ASCE)0733947X(2006)132:2(141)

Panthi, K. (2009). A Methodological Framework for Modeling Pavement Maintenance Costs for Projects with Performance-based Contracts. Florida International University. https://doi.org/10.25148/etd.FI09120824

Paterson, W. O. (1994). Highway Development and Management: A Vision of What We Need To Do A Better Job. In Proceeding of the International Workshop on HDM-4. Kuala Lumpur.
Pérez-Acebo, H., Bejan, S., \& Gonzalo-Orden, H. (2017). Transition Probability Matrices for Flexible Pavement Deterioration Models with Half-Year Cycle Time. https://doi.org/10.1007/s40999-017-0254-z

Prasetyo, R. B., \& Firdaus, M. (2009). Pengaruh Infrastruktur Pada Pertumbuhan Ekonomi Wilayah Di Indonesia. Jurnal Ekonomi Dan Kebijakan Pembangunan, 2, 222-236.

Surendrakumar, K., Prashant, N., \& Mayuresh, P. (2013). Application Of Markovian Probabilistic Process To Develop A Decision Support System For Pavement Maintenance Management, 2(8), 295-303.

Tjan, A., \& Pitaloka, D. (2005). Future Prediction of Pavement Condition Using Markov Probability Transition Matrix. In Proceedings of The Eastern Asia Society for Transportation Studies (Vol. 5, pp. 772-782). 
151 Sazali, A. dkk. Aplikasi Model Rantai Markov Dalam Pengelolaan Jalan... 